\title{
Ustekinumab ved Crohns sykdom
}

\author{
Antistoffet ustekinumab gir rask bedring hos pasienter med Crohns syk- \\ dom som ikke har hatt effekt av konvensjonell behandling. Dette viser en \\ ny studie.
}

Det monoklonale antistoffet ustekinumab brukes ved behandling av psoriasis. I to fase 3studier med til sammen 1369 pasienter ble effekten av stoffet ved Crohns sykdom evaluert (1). I den ene studien hadde pasientene hatt primær eller sekundær behandlingssvikt eller uakseptable bivirkninger med tumornek-

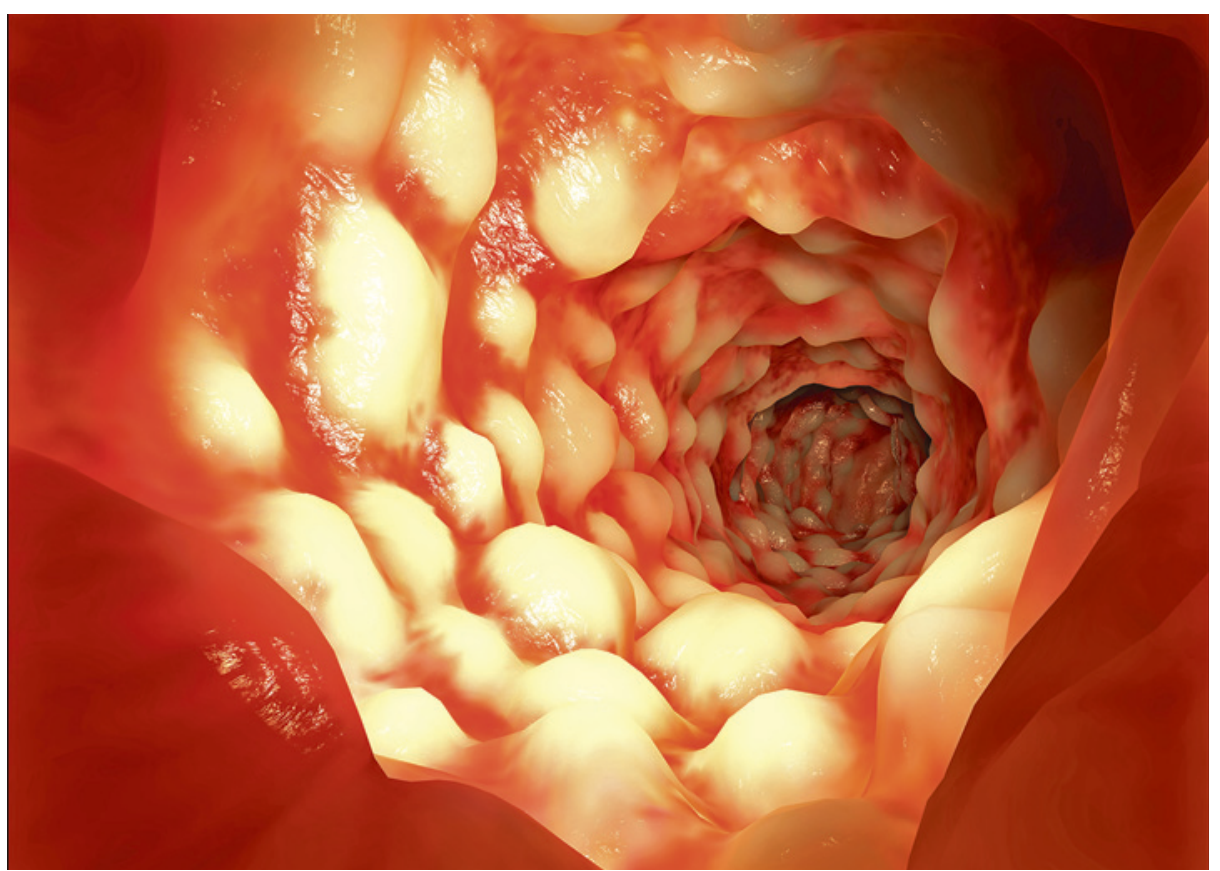

Illustrasjon: Thinkstock rosefaktor (TNF)- $\alpha$-hemmere. I den andre studien hadde pasientene hatt manglende effekt eller uakseptable bivirkninger av immunsuppressive medikamenter eller glukokortikoider.

Pasientene ble randomisert enten til ustekinumab gitt som én enkelt intravenøs dose, enten $130 \mathrm{mg}$ eller $6 \mathrm{mg} / \mathrm{kg}$, eller til placebo.
Klinisk respons ble definert som en reduksjon i CDAI-indeksen (Crohn's Disease Activity Index) på minst 100 poeng fra studiestart eller CDAI $<150$. Pasienter med klinisk respons ble deretter blokkrandomisert til en vedlikeholdsstudie med subkutan injeksjon av ustekinumab hver 8 . eller 12 . uke eller placebo i totalt 40 uker.

Seks uker etter infusjonen var det flere av dem som var behandlet med ustekinumab som oppnådde klinisk bedring enn av dem som var behandlet med placebo. Dette gjaldt begge studiene, henholdsvis $34,3 \%$ og $33,7 \%$ versus $21,5 \%(\mathrm{p}<0,003)$ og $51,7 \%$ og 55,5\% versus $28,7 \%(\mathrm{p}<0,003)$ Av de nesten 400 pasientene som fikk vedlikeholdsbehandling hver 8 . eller 12. uke, var henholdsvis 53,1\% og 48,8\% i remisjon etter 44 uker - versus $35,9 \%$ i placebogruppen.

- Ustekinumab er et viktig bidrag $\mathrm{i}$ behandlingen av Crohns sykdom, sier Jørgen Jahnsen, overlege ved Avdeling for fordøyelsessykdommer, Akershus universitetssykehus, og professor ved Universitetet i Oslo. - Studien viser tydelig at medikamentet har god effekt både som akutt- og vedlikeholdsbehandling også hos dem som ikke har hatt nytte av annen biologisk behandling. Bortsett fra den initiale infusjonen administreres ustekinumab som en subkutan injeksjon som pasientene kan håndtere selv, og det er positivt.

Kari Tveito

Tidsskrifte

\section{Litteratur}

1. Feagan BG, Sandborn WJ, Gasink C et al. Uste-

kinumab as induction and maintenance therapy for

Crohn's disease. N Engl J Med 2016; 375: 1946-60.

\section{Bedre behandling ved inflammatorisk tarmsykdom?}

\section{Et protein som binder interleukin 22 ser ut til å inngå i virknings- mekanismen for tumornekrose- faktor- $\alpha$-hemmere.}

Monoklonale antistoffer rettet mot tumornekrosefaktor- $\alpha$ (TNF- $\alpha$ ) brukes bl.a. ved ulcerøs kolitt og Crohns sykdom, men virkningsmekanismen er ikke helt klarlagt. En ny studie som nylig er publisert i tidsskriftet Science, kaster nytt lys over hvordan TNF$\alpha$-hemmere kan virke (1).

Interleukin 22 (IL-22) kan nedregulere uønskede immunreaksjoner. CD4-positive celler isolert fra inflammerte områder av tarmen utskiller både IL-22 og IL-22-bindende protein (IL-22BP), som hemmer effekten av
IL-22. Ved divertikulitt virker samspillet bra ved at IL-22-produksjonen øker, mens IL22BP blir mindre uttrykt. Ved inflammatorisk tarmsykdom er derimot IL-22BP-nivået øk, slik at den potensielt helende effekten av IL-22 svekkes. IL-22BP-produksjonen i de isolerte CD4-positive cellene ble tydelig redusert hos pasienter som responderte på behandling med TNF- $\alpha$-hemmer, men ikke hos dem som ikke responderte. En patogenetisk betydning av høyt IL-22BP-nivå ble støttet av en rekke forsøk med en musemodell. Behandling direkte rettet mot IL-22BP kan tenkes å hjelpe pasienter med inflammatorisk tarmsykdom som har dårlig effekt eller bivirkninger av TNF- $\alpha$-hemmere.

- Monoklonale antistoffer mot TNF- $\alpha$ har revolusjonert behandlingen av inflammatorisk tarmsykdom, men det er langt fra alle pasienter som har effekt av behandlingen, sier Knut E.A. Lundin, som er professor ved Institutt for klinisk medisin, Universitetet $\mathrm{i}$ Oslo. - Dysregulering av IL-22BP kan tenkes brukt terapeutisk, men det er langt frem dit. Det er for eksempel ukjent hvilke bivirkninger anti-IL-22BP-antistoffer eller andre IL-22BP-antagonister vil kunne ha - med eller uten samtidig behandling med en TNF$\alpha$-hemmer, sier Lundin, som gjerne vil ha flere terapeutiske muligheter ved ulcerøs kolitt og Crohns sykdom.

\section{Haakon B. Benestad}

Universitetet i Oslo

\section{Litteratur}

1. Pelczar P, Witkowski M, Perez LG et al. A pathogenic role for T cell-derived IL-22BP in inflammatory bowel disease. Science 2016; 54: 358-62. 